003.3(091)

https://doi.org/10.18485/mks_srpska_slavistika.2018.1.ch27

\author{
Вања С. СТАНИШИЋ* \\ Универзитет у Београду \\ Филолошки факултет \\ Катедра за српски језик са јужнословенским језицима
}

\title{
ПАРАДИГМАТИКА И СИНТАГМАТИКА НЕСАМОСТАЛНИХ ГРАФЕМА И ДВА ТИПА ОРТОГРАФСКИХ СИСТЕМА У ЕВРОПСКИМ ПИСМЕНОСТИМА
}

\begin{abstract}
Током свога развоја наука о писму прошла је пут од једне помоћне историјске дисциплине, рођене при крају XIX в., до самосталне научне области, по методу и научном приступу тесно повезане с модерном науком о језику. Методолошко приближавање науке о писму с науком о језику почива на чврстој међусобној вези између језика и писма, која је у науци о писму разрађена управо применом читавог низа операционалних појмова и техника лингвистичке анализе. Двострану природу писма, чију унутрашњу структуру условљавају језичке појаве, а спољашњу форму културна историја, илуструје и структуралистичка подела на парадигматику и синтагматику писма. Као што ћемо покушати да покажемо, ова два плана могу бити драгоцена за боље разумевање односа између графема и фонема с посебним освртом на два типа европских писмених система.

Кључне речи: парадигматика и синтагматика писма, несамосталне графеме, диграфи, лигатуре, дијакритике.
\end{abstract}

Поделу на парадигматику и синтагматику увео је у словенску палеографију Јирген Кристофсон (Jürgen Kristophson) 1986. године у виду „парадигматске и синтагматске ортографије". Истовремено, то је био и један од првих радова примене графолингвистичког приступа у словенској палеографији. У даљем развоју словенске палеографије разрађују се многа питања графолингвистичке проблематике, али је подела на парадигматику и синтагматику ретко бивала у центру пажње. ${ }^{1} \mathrm{y}$ томе раду, који је настао пре стасања савремених графолингвистичких истраживања,

*vanjast61@gmail.com

${ }^{1}$ Још 1990. Тамаз Гамкрелидзе је своју типолошку класификацију средњовековних алфабета грчкога круга засновао управо на подели на парадигматику и на синтагматику писма, која је у најширем смислу омогућила разликовање система и структуре и убедљиво показала блиску везу између науке о језику и науке о писму. Зато је Гамкрелидзеова студија имала већег одјека у науци о писму него у палеославистици (Станишић 2014: 153). 
који наглашавају самосталност писаног језика, Кристофсона је претежно интере-

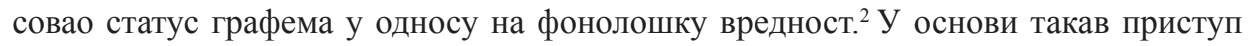
„имплицитне графолингвистике” даље разрађују Борјана Велчева (Боряна Велчева) и Ана-Марија Тотоманова (Анна-Мария Тотоманова), ${ }^{3}$ чији су радови били подстицајни за аутора овога рада да се и сам позабави питањима односа између графема и фонема у словенској писмености, разрађујући их у духу традиционалне терминологије и не упуштајући се у шира теоријска питања. ${ }^{4}$ Ближе упознавање с аутономном структуром и системном организацијом графичких елемената текста временом је довело до уобличења графолингвистике с унутрашњом поделом на графемику, непосредно везану за језичку основу текста, и на графетику, која се односи само на визуелне (графичке) чиниоце писмене комуникације. ${ }^{5}$

Својеврсну прекретницу у графолингвистичком утемељењу словенске палеографије означили су радови Хајнца Микласа (H. Miklas), који је први применио приступ и терминологију немачке графолингвистике на старословенски материјал, тачније на његов ћирилички корпус. ${ }^{6}$ Дијакритике су код њега „несамосталне графеме”, које се у старословенском графичком систему даље деле на супралинеарне (титла и апостроф), линеарне (интерпункција), сублинеарне знаке (нпр. ознака за број 1000). Ова целовита и заокружена класификација старословенских графичких средстава добила је даљу разраду и монументалну рекапитулацију на глагољичком корпусу у Графолингвистици Матеа Жагара (Žagar 2007).

Овај рад представља осврт на парадигматски и синтагматски статус несамосталних графема у писменим системима на тлу Европе, који би се на основу тога могли поделити у две групе.

Парадигматски и синтагматски план налазе се у основи самих правила по којима се уређују односи између одговарајуће језичке основе и њене графичке форме, што се може видети и на основу разлика између графике и ортографије. Прва се може дефинисати као „свеукупност веза између графичких и гласовних јединица", која је нераскидиво повезана с п а ра д и г мат и ко м писма као инвентаром писмених знакова или уређеним списком графема (нпр. алфабетом или силабаријем), док је друга систем правила којима се уређују те везе, тј. с и н тагматика писма. Дакле, док се прва ограничава само планом израза, друга је због своје везаности за више језичке нивое подложна различитим утицајима језичке и ванјезичке стварности, те стога укључује и план садржаја (Зиндер 1987: 58; Амирова 1977: 54, 89).

У оквиру тих веза између графичких и гласовних јединица посебно место заузимају диграфи, сложене графеме, који сведоче о битној разлици између графема и слова, садржаној у чињеници да ове сложене графеме припадају синтагматском плану, а слова парадигматском. Иако се ове сложене графеме структурно разликују од фонема, то нису слободне комбинације слова већ целовите јединице

\footnotetext{
${ }^{2}$ Наведено према Жагару (Žagar 2007: 68).

${ }^{3}$ Велчева 1971, Velčeva 1988; Тотоманова 1992.

${ }^{4}$ Упор. Станишич 1994, Станишић 2006, Станишић 2008, Stanišić 2010.

${ }_{5}^{5}$ Њихов се развој може пратити од Лексикона германистичке лингвистике Ханса Алтхауса (Althaus 1973), Историје и теорије графемике Тамаре Амирове (Амирова 1977), Графичких елемената писанога језика Петера Галмана (Gallmann 1985), као и Прегледа опите теорије писма Лава Зиндера (Зиндер 1987), чији је стожерни део посвећен управо графолингвистичкој проблематици.

${ }^{6}$ Miklas 1988, Миклас 1993, Miklas 2000. Упор. Žagar 2007: 70.
} 
које функционишу као графеме. Зато њихов број може бити далеко већи од броја слова. У енглеском алфабету, нпр., њихов однос може ићи од поклапања графеме и слова па до четири пута већег броја знакова у сложеној графеми: a, aa, ar, air, aigh итд. (Амирова 1977: 93-95).

Укључењем у алфабетски списак диграфи прелазе у парадигматски план и постају „квази-лигатуре”. Оне су по правилу крајње ретке у западноевропским ортографијама. ${ }^{7}$ То је, међутим, карактеристична одлика читавог низа средњоевропских латиничких система. У мађарском и албанском има чак девет таквих графема (мађарски $c s, d z, d z s, g y, l y, n y, s z, t y, z s$; албански $d h, g j, l l, n j, r r, s h, t h, x h, z h$ ). Њихова сложена консонантска решења, којима се бележи комплетан систем африкатских парова и медиопалатали заједничких полуеманципованих консонантских система срећу се у појединим решењима и у суседним словенским језицима. ${ }^{8}$ У словачком се тако бележе такође африкате $d z, d \check{z}$, при чему словачки с чешким спаја и графема $c h$, која у ова два језика служи за опозицију између двају /x/ [ $:$ х]. Поред квазилигатуре $d z ̌$, у савременој хрватско-српској латиници тако се обележавају палатални сонанти $n j, l j[\mathrm{n}, K]$, који су, судећи по дијалекатској основици њихова изумитеља Људевита Гаја, могли изворно такође имати медиопалаталну артикулацију (као и у савременој словеначкој ортографији). ${ }^{9}$ Као што је познато, није успео покушај Ђуре Даничића (који је 1880. уместо Гајевих $d \check{z}, d j, l j$ и $n j$ био предложио дијакритичке $\langle\dot{\mathrm{g}}\rangle,\langle\mathrm{d}\rangle,\langle\underline{l}\rangle$ и $\left.\langle\hat{\mathrm{n}}\rangle)^{10}\right)$ да хрватско-српску латиницу ортографски усклади с њеном штокавском дијалекатском основом и да је у крајњој линији усклади с Вуковим ћириличким простим графемама ћ, ђ, џ, љ, њ. ${ }^{11}$ У том смислу, по својим квази-лигатурним решењима Гајева ортографија управо одговара такође квази-лигатурној ћирилици Саве Мркаља. ${ }^{12}$

Ако између диграфа и лигатура постоје алографска варирања унутар истог ортографског система, односи међу њима се уређују позицијом или графичким контекстом, која се остварује обостраним деловањем графике и ортографије (Маслов 1973: 222; Зиндер 1987: 85-87). То је истовремено најважнији чинилац који омогућава разликовање графема и њихових позиционих варијанти - алографа. Пример необавезних (факултативних) односа међу њима, који се још зову и „,рафономским варирањима", представља статус средњовековне латинске лигатуре $\langle æ\rangle$, која се још увек може срести као алограф диграфа ае у енглеском и француском („Æneas”). У данском је то структурна лигатура смештена у алфабетском списку после $\langle\mathrm{z}\rangle$. Између тих двеју графема у данском се раније налазила и квази-лигатура $a a$, која је данас остала само варијанта дијакритичког 〈å), ограничена на топониме и лична

${ }^{7}$ Најсложенији је пример велшког алфабета, који садржи чак осам таквих графема $(c h, d d, f f, l l, n g$,

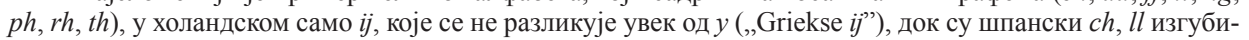
ли посебно место у алфабетском списку 90-их година прошлог столећа.

${ }^{8}$ Више о томе упор. Sawicka 1997, Sawicka 2001 (нарочито друго поглавље [Chapter II, 35-]).

${ }^{9}$ Гај је, додуше, прву верзију своје ортографије из 1830. штампао „чешким” решењима $\langle\check{c}\rangle,\langle\check{z}\rangle,\langle\check{s}\rangle$, $\langle\check{\mathrm{n}}\rangle,\langle\tilde{1}\rangle,\langle\breve{\mathrm{g}}\rangle,\langle\mathrm{t}\rangle($ Gaj 1830).

${ }^{10}$ Данас се одржало само 〈đ〉 (пореклом ознака за стари германски дентални спирант, упор. Ђурић 1976),

${ }^{11}$ Последње две, попут грчкога $\omega$ и латинскога w, спадају, према Жагару, у тзв. ,дубинске (повијесне)” лигатуре (Žagar 2007: 406).

${ }^{12}$ Мркаљ је још 1810. графички издвојио особени штокавски палатални ред помоћу квази-лигатура („сложених писмена”) $\langle$ ть $\rangle$, 〈дь $\rangle,\langle л ь\rangle,\langle н ь\rangle$, и у српску писменост први увео већ поменуто фонетско начело ,јединозвучности" (Станишић 1987: 27). 
имена (Kierkegaard (Rogers 2005: 12)). Ако се пак такве две графеме никад не могу наћи у истом контексту, онда је реч о „комплементарној дистрибуцији”, какав је нпр. случај с различитим начинима бележења зубног безвучног спиранта [s] у немачком, који се не може означити истим знаком (алографом $s$ ) између два вокала пошто у том положају овај знак служи за означавање његовог звучног парњака [z]. Зато се за означавање фонеме [s] у међувокалном положају користе диграф ss и данас оригинална немачка лигатура „eszett” $\beta$ - пореклом готички диграф sz (ß), који је данас напуштен у немачком стандарду на тлу Швајцарске (што би могао бити одраз локалних прилика у вишејезичној швајцарској средини). ${ }^{13}$ Поменути знаци су, међутим, важни маркери квантитетских односа у немачкој ортографији: диграф се користи после кратких слогова (да, по аналогији са старом праксом у западноевропским језицима, својом удвојеношћу истакне њихову краткоћу), а лигатура после дугих: masse [mase] „маса”, küssen [kysən] „пољубити” : grüßеn [gьу:sən] „поздравити", gießen [gi:sən] „лити”; buße [bu:se] „покајање, испаштање” : busse [buse] „аутобуси”. Један од најстаријих типова сличне комплементарне дистрибуције у словенској писмености био је преузет из грчке опозиције између двају знакова за /u/, квази-лигатуре or и лигатуре 8, која се од првобитног маркера краја реда ${ }^{14} \mathrm{y}$ црквенословенском проширила на све унутрашње слогове, док је оү временом ограничен само на почетни положај (оүччкни́къ : zа8̈тра, р8ка́ (Ambrosiani 1996: 2-3)).

Графономска варирања и комплементарна дистрибуција показују се као два еволутивна и хронолошка типа алографије, као семантичка и несемантичка улога алографа, која сведочи о крупним променама које је, на словенском примеру, доживео црквенословенски фонолошки систем у своме хиљадугодишњем преображају од старословенског до новоцрквенословенског језика. Док су стсл. знаци $\mathbf{~} \mathbf{t} \mathbf{m}, \mathbf{z}$, є током средњег века постали графономске варијанте других знакова и временом напуштени, дотле је у новоцрквенословенском успостављена комплементарна дис-

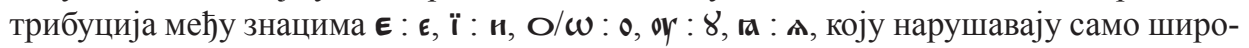
ке графичке могућности овог језика, добро позната широка примена ових знакова у неутралисању хомонимије.

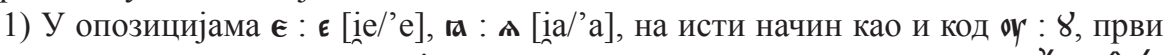
је ограничен на почетни положај у речи, а други на унутрашње слогове: йжє є̂́є́,

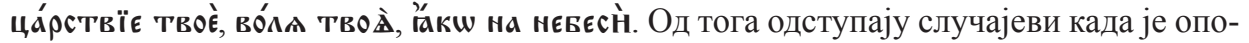
зиција $\boldsymbol{\epsilon}: \boldsymbol{\epsilon}$ искоришћена за графичко уклањање падежне хомонимије: Н. јд. єิ Ай́'ъ ста́рєцъ : Г. мн. єૈдйнъ $\omega$ ста́рєцъ, И. јд. по́лемъ : Д. мн. по́лємъ, Ак. јд. мєнѐ : ồ мєнё. Лексичка хомонимија пак играла је улогу у нарушавању односа између

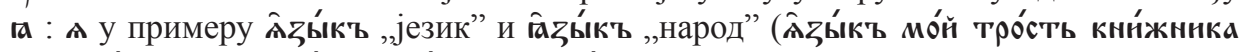
скоропи́сца : по п४те́мъ г̆ъи́къ не оү̆чи́тесА). ${ }^{15}$

2) У опозицији двају [i] ï(í) : и прво је ограничено на превокални положај само

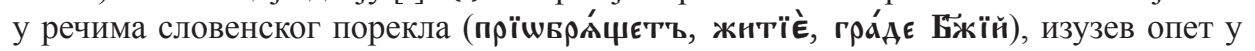
случајевима уклањања хомонимије, где се, као и у несловенској лексици, ово ї „де-

\footnotetext{
${ }^{13}$ Упор. Ulbrich 2006.

${ }^{14}$ При чему се лигатура могла наћи и на почетку речи, ако је ту био крај реда, нпр. у струс. Житију Нифонта из 1222: и 8|ничьжаше сєьє (Пономаренко 2009: 203).

${ }^{15}$ Црквенословенски примери се наводе према Атанасију Бончеву (1995).
} 
сетерично” може наћи и пред сугласником: Фїкі́ппъ, мі́ръ „свет” : ми́ръ „мир”

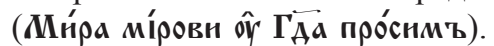

3) У опозицији трију знакова за [o] O/w : 0 „широко $o$ ” и грчка „омега” графономски варирају на почетку речи, док се обе супротстављају „обичноме $o$ ”, ограни-

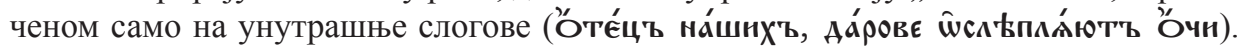
Као и у претходним случајевима, комплементарну дистрибуцију и овде неутралишу разлози уклањања падежне хомонимије (Н. јд. проро́къ : Г. мн. прори́къ, И. јд. оүิчєнико́мъ : Д. мн. оүүчєники́мъ), или лексичка одступања где се „омега” може

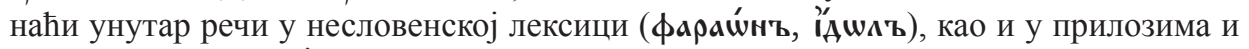
везницима (мно́гw, '̌́кw).

Као што се види, у неутралисању синтагматски засноване комплементарне дистрибуције поменутих алографа одлучујућу улогу је имао парадигматски план, који препознајемо пре свега у падежној хомонимији.

Историјски контекст још је изразитији код тзв. историјских псеудоалографа, које илуструју односи између диграфа $\langle\mathrm{ph}\rangle$, 〈th $\rangle$ и одговарајућих простих графема $\langle\mathrm{f}\rangle,\langle\mathrm{t}\rangle$ у западноевропским алфабетима (франц. forme : philosophe, tête : théâtre), типолошки истоветних статусу црквенословенских алографа $\langle\boldsymbol{\bullet}\rangle,\langle\boldsymbol{w}\rangle,\langle\boldsymbol{v}\rangle$, као маркера грчке лексике (өrsмїа́мъ, •өwмá, сгно́дъ). Ови знаци, по Зиндеровим речима (1987: 82), нису алографи пошто не зависе од позиције, нити су графеме пошто никад не стоје у опозицији према некој другој графеми. Пошто њихова употреба не зависи ни од језика, ни од графије, они би структурно били најближи појму факултативних варијанти графема, као маркеру културне историје. Такве је облике Јуриј Маслов веома прикладно назвао „цитатним”, јер немају никакве везе с алографима графијског система у којем се употребљавају (Маслов 1973: 221; Зиндер 1987: 89), баш као што би се могао назвати и оригинални, неприлагођени изговор страних речи, јер ни он најчешће нема никакве везе с алофонима фонетског система у којем се употребљавају.

Псеудоалографи спадају међу знаке који немају гласовну, него метајезичку улогу. Једну од најважнијих функција те врсте имају дијакритике, несамостални графички елементи који врше улогу допунског обележја или модификације значења основних знакова. Оне су универзална одлика свих типова писма. У идеографији мењају значење знака, а у фонографији изговор. При томе су дијакритике у идеографији по правилу прости графички елементи, попут цртица на лицу сумерског пиктограма „глава” 4 . добио значења „уста” ka и „говорити” dug (Rogers 2005: 88). У кинеском писму такву одлику има категорија индикатора, у којој се помоћу дијакритичке цртице модификује значење основног знака, као у примерима 曰 $y и \bar{e}$ „говорити” (уста 口 kǒи с дијакритиком која указује на извор говора) и 本 běn „корен, изворник” (дрво 木 тѝ с дијакритиком која указује на његов корен) - категорија која се развила још у најстаријем раздобљу кинеског писма (у коштаним знацима $\boldsymbol{E}$ и писму печата 岗).

С тим у вези, пада у очи секундарни (неизворни) карактер дијакритика у фо-

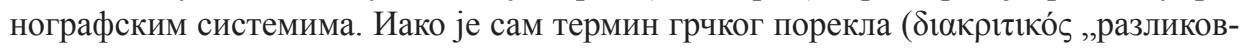




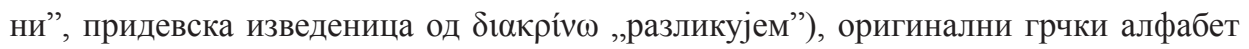
није познавао дијакритике. Најраније се појавио непроизвољни графички знак, настао преображајем одговарајуће графеме - модел који данас има бројне паралеле у западноевропским алфабетима. Семитски веларни спирантски пар $\exists$ [he], [het] послужио је у грчком за квантитетску опозицију између $\langle\varepsilon\rangle:\langle\eta\rangle$, при чему је ово друго (дуго [е:]) у већини дијалеката дуго чувало спирантску артикулацију, да би временом изгубило равноправан статус и претворило се у пратеће спирантско обележје, ограничено у класичном јонско-атичком само на иницијални превокал-

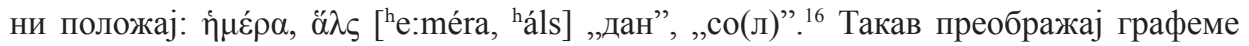
у дијакритику - у артикулационо обележје другог знака $\left(\mathrm{H} \rightarrow{ }^{\mathrm{h}} \rightarrow^{\mathrm{c}}\right)$ поновљен је касније и у неким западноевропским алфабетима, попут немачких умлаутних 〈ä〉, $\langle\ddot{o}\rangle,\langle\ddot{u}\rangle$, који потичу од диграфа $\langle\mathrm{ae}\rangle,\langle\mathrm{oe}\rangle,\langle\mathrm{ue}\rangle\left(\rightarrow\left[\mathrm{a}^{\mathrm{e}}, \mathrm{o}^{\mathrm{e}}, \mathrm{u}^{\mathrm{e}}\right]\right)$. Подударни умлаутни дијакритички знаци добили су пак посебно место у алфабетском низу у северним германским језицима (шведском: 〈ä $\rangle,\langle\ddot{\partial}\rangle,\langle a ̊\rangle$, данском и норвешком: $\langle a ̊\rangle,\langle ø\rangle)$. Слично нарушавање парадигматског плана одиграло се и на крајњем југу западноевропског културног простора, где је латински алфабетски низ од 26 графема у шпанском

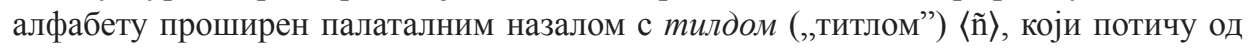
диграфа $n n\left(\rightarrow \mathrm{n}^{\mathrm{n}}\right)$. Дијакритички карактер ове графеме, која одражава хиспаноромански изговор меких $[\Lambda, \mathrm{n}]$ као напрегнутих, ,амбисилабичких” [11, nn], наслеђен је из раносредњевековних курзива и стенографије, који су тада цветали по манастирским скрипторијима. Од бројних лигатура и дијакритика тога раздобља преживела је још само такође изворно шпанска zedilla „мало $z$ [zed]” у саставу графеме $\langle c ̧\rangle$, од диграфа $\langle\mathrm{cz}\rangle$ (као првобитне ознаке за африкату [ts]), која је у француском и португалском данас остала као синтагматска дијакритичка ознака изговора графеме $\langle\mathrm{c}\rangle$ као [s] пред вокалима [a, o, u]. ${ }^{17}$ Међутим, по своме ексклузивном парадигматском статусу, шпанска графема $\langle\tilde{n}\rangle$, која у овом смислу има апсолутни пандан у поменутој немачкој лигатури $\langle ß\rangle$, постала је изразито етно-лингвистичко обележје, тако да су покушаји њеног изостављања у међународној комуникацији у хиспанофоним круговима били доживљени као атак на идентитет. ${ }^{18}$

Посебан је случај тзв. парадигматских дијакритика - графема које су делимично или у целини изгубиле гласовну вредност и добиле улогу допунског обележја других знакова. Такву је судбину доживела графема $\langle\mathrm{h}\rangle$ у народном латинском и стога добила широку дијакритичку примену у западноевропским ортографијама. Од ознаке дужине у послевокалном положају у немачком (mahlen [ma:len] ,/са/млети" - malen „,на/сликати”, ihm [i:m] „њему” - im ,у”) и одсуства елизије у француском (le homard [lə omar] ,jастог") до маркера палатаности и медиопалаталности у саставу разних диграфа (〈ch $\rangle,\langle\mathrm{sh}\rangle,\langle\mathrm{gh}\rangle,\langle\mathrm{lh}\rangle,\langle\mathrm{nh}\rangle)$ у многим западноевропским језицима. То исто важи и за функцију јерова у црквенословенском, а одатле и у руском, где су они постали ознаке за умекшан или неумекшан изговор сугласника у одређеним положајима: цсл. конь [кон'], зако́нъ [зако́н], ц‘вььва̀ [цел’бá], рус. ходьба [ход’бá], бурьян [бур'ја́н], подъем [подјо́м].

\footnotetext{
${ }^{16}$ Гамкрелидзе 1989: 225; Threatte 1996: 276; Rogers 2005: 158-159.

${ }^{17}$ Tuttle 1996: 634-635.

${ }^{18}$ Упор. Blog de Luis Durán Rojo. 18/11/07: El triunfo de la Ñ - Afirmación de Hispanoamerica.
} 
Поделу на парадигматику и синтагматику налазимо и код тзв. правих дијакритика. Прве се такође зову идиоматске, тј. оне које се везују само за једно одређено слово, док су друге аналитичке - оне којима се означава одређена диференцијална одлика својствена читавој групи гласова (Зиндер 1987: 62-63). Исти знаци у зависности од система могу да добију претежно идиоматску или претежно аналитичку улогу, при чему знаци прве категорије по правилу могу да постану саставни елемент појединих графема и да увећају укупан број слова у одређеном писму - упор. знак циркумфлекс $\langle\wedge\rangle$, који у француском алфабету указује на природу изговора појединих вокала (mâcher „жвакати”, maître „господар”, те̂те „исти”), док је у румунском

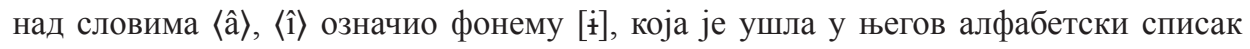
(România, inainte „напред”). Притом, питање избора једног или другог модела не зависи толико од језичког система колико од културне историје. Несклоност западноевропских ортографија да нарушавају парадигматику латинског писма сведочи о старој етно-културној идентификацији с графички јединственим цивилизацијским наслеђем оличеним у латинском писму, која је била старија и важнија од локалних језичких разлика. Превасходно синтагматски карактер несамосталних графема у западноевропским латиничним системима има паралелу у појави грчких акцената тек у хеленистичком периоду, као и дијакритичкој вокализацији хебрејског и арапског писма - увођењу кратких вокала, у хебрејском ради прецизирања изговора, а у арапском случају ради мисионарског рада - ширења ислама међу неарапским народима (Rogers 2005: 127, 132-133). У свим овим случајевима разлог је био углед, па чак и светост графичког културног наслеђа.

Насупрот западноевропском, у латиничним системима Средње и Источне Европе влада другачији ортографски принцип и несамосталне графеме, како је већ било речено, у њима имају пре свега парадигматски карактер. Као што је познато, они су настајали у другом времену, у доба превођења Библије на националне језике, којем је главни печат дао Јан Хус својим револуционарним реформаторским подухватом. Без обзира на различита коначна решења, условљена како различитим језичким структурама, тако и разликама идеолошке природе, његов ортографски принцип ,један глас - једно слово” нашао је непосредан одјек при стварању мађарске, пољске и словачке ортографије. ${ }^{19}$ Иако питање порекла Хусове дијакритичке ортографије остаје отворено, стоји чињеница да је ортографски модел ,једно слово - један глас" заједно с подударним дијакритичким обележавањем палаталности сугласника постојао управо у словенској писмености, која је у Хусово време још увек постојала у Чешкој, па се због тога не може искључити могућност да се у његовом графичком систему можда налази и одјек словенске писмене традиције. ${ }^{20}$

Заиста, ако се у словенском диграфу 〈29 / or) препознаје грчки модел синтагматског начина бележења вокала [u] (без обзира што је он у словенском ушао у азбучни списак и заузео оно место и бројну вредност [400], коју у грчком алфабету има $\langle v\rangle)$, онда би се и у Хусовом укидању полифункционалности латинскога 〈c〉 [ts/k] и парадигматском раздвајању тих двеју артикулација, могло видети управо

\footnotetext{
${ }^{19}$ Упор. преглед овог питања у колективној студији The Insect Project (2016).

${ }^{20}$ Упор. о томе питању: Станишич 1994; Станишић 2008.
} 
„slavisches Schriftdenken”. ${ }^{21}$ То би се могло рећи и о дијакритичком начину обележавања палаталности сугласника, које је у словенском било идиоматско и само синтагматско. Иако су меки сонанти [ŕ, l', ń] реконструисани за позни прасловенски, они нису нашли место у самој азбуци, али је њихова посебна гласовна вредност ипак дошла до изражаја у појединим споменицима. Сама чињеница да су они били бележени само синтагматски тешко да може бити случајна. Преформулација гр-

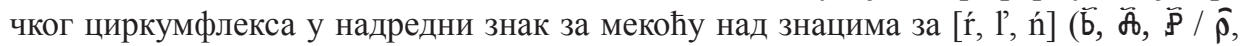
$\overline{\mathbf{\Lambda}}, \hat{\mathbf{A}})$, доследно спроведена само у Зографском јеванђељу и Супрасаљском зборнику, сведочи о различитој еманципацији ових меких сугласника у старословенском. Уобличавањем јотованих лигатура у традиционалној ћирилици, карактеристичној за источнословенске језике и бугарски, палатална опозиција прешла је на парадигматски план и он одражава систем с палаталном корелацијом сугласника, који је произвео велики број полумеких сугласника у овим језицима. С друге стране, у словенским латиничким писменостима чешкога типа јасно се издваја дијакритички обележен палатални сугласнички ред, који стоји у опозицији према свим осталим сугласницима. Исти системни разлози довешће до еманципације овога реда и у српској ћирилици, која током читаве своје историје показује тежњу да графички изрази систем с палаталним редом који постоји у српском језику. ${ }^{22}$

Као што се види, парадигматски и синтагматски план несамосталних графема може бити значајан за боље разумевање односа између језичке основе и графичке форме писмених система, у датом случају да баци ново светло на знатне разлике које у овом смислу постоје међу писменостима европског простора.

\section{Лuтература}

Амирова, Т. А. К истории и теории графемики, Москва 1977.

Бончев А. Църковнославянска граматика със сборник от образии за превод. Велико Търново, 1995

Велчева Б. „Най-ранните абецедари като източник на езикови данни.” КонстантинКирил Философ: Доклади на симпозиума посветен на 1100-годишнината от смърта му. София, 1971: 185-186.

Гамкрелидзе Т. В. Алфавитное письмо и древнегрузинская письменность. Типология и происхождние алфавитных систем письма. Тбилиси, 1989. [ю. дыдуюумодл,

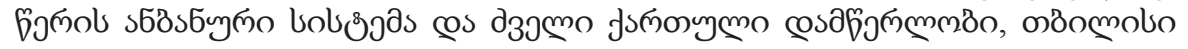
1989].

Ђурић В. Књига Ђуре Даничића. Прир. В. Ђурић. Београд: СКЗ, 1976.

Зиндер Л. Р. Очерк общей теории письма. Ленинград, 1987.

Маслов Ю. С. „Заметки по теории графики.” Psychologica: Исследования по языку и литературе. Ленинград, 1973: 220-226.

${ }^{21}$ У оном смислу у којем је Трубецкојев појам „грчкога графичког мишљења” (griechisches Schrifdenken) на словенском материјалу даље разрадио Хајнц Миклас (Miklas 1998; Žagar 2007: 72-73).

22 Упор. Станишић 2008: 234-235. 
Миклас X. „От преславския събор до Преславската школа. Въпроси на графемиката.” Palaeobulgarica, XVII (1993/2): 3-12.

Пономаренко Т. О. 2009: „Дистрибуция графем в дублетном звене or - r -8 в Житии Нифонта 1222 г.” Грамота, № 2 (4) (2009), 202-204.

Станишић В. „Корени и домети Вукове реформе српске ћирилице.” Повеља, 1-2 (1987): 24-45.

Станишич В. „Глаголица и фонетические алфавиты средней Европы.” Balcanica, XXV-1 (1994): 267-285.

Станишић В. „О неким питањима унутрашње реконструкције прасловенског гласовног развоја.” Јужнословенски филолог, LXII (2006): 139-154.

Станишић В. „Парадигматика и синтагматика старословенске двоазбучности.” Нaучни састанак слависта у Вукове дане (13-16. 9. 2006), 36/3. Београд: МСЦ, 2008: 231-239.

Станишић В. „Словенска писменост и средњовековни алфабети грчкога круга.” Свети Ћирило и Методије и словенско писано наслеђе: 863-2013, Старословенско и српско наслеђе I. Београд: Институт за српски језик САНУ, 2014: 151-168.

Тотоманова А-М. Из българската историческа фонетика. София: Университетско издателство Св. Климент Охридски, 1992.

Ambrosiani P. „Internal analysis of Church Slavic orthography.” Studies in South Slavic and Balkan linguistics, Studies in Slavic and General linguistics, vol. 23. Ed. by A. A. Barentsen. Amsterdam - Atlanta, 1996: 1-20.

Althaus H. P. Lexikon der germanistischen Linguistik. Hrsg. H. P. Althaus. Tübingen, 1973.

Bálik P. „Designing Slovak diacritics.” The Insect Project : Problems of diacritic design for Central European languages. Katowice, 2016: 94-115.

Blažek F. „Czech diacritics: from Hus to Unicode.” The Insect Project : Problems of diacritic design for Central European languages. Katowice, 2016: 12-35.

Gaj L. Kratka osnova horvatsko-slavenskoga pravopisaňa. Budim, 1830.

Gallmann P. Graphische Elemente der geschriebenen Sprache. Tübingen, 1985.

Kravjanszky R. „The case of Hungary.” The Insect Project : Problems of diacritic design for Central European languages. Katowice, 2016: 41-53.

Kristophson J. Klassifikation von Orthographiesystemen: Ein Beitrag zum Verhältnis von Sprache und Schrift. Dargestellt am Beispiel slavischer kyrillischer Orthographien. Neuried, 1986.

Małecka A. Oslislo Z. „Polish diacritics: the history and principles of design.” The Insect Project : Problems of diacritic design for Central European languages. Katowice, 2016: 64-91.

Miklas H. „Zur Struktur des kyrillisch-altkirchenslavischen (albulgarischen) Schriftsystems." Palaeobulgarica, XII/3 (1988): 52-65.

Miklas H. „Griechisches Schriftdenken und slavische Schriftlichkeit / Glagolica und Kyrillica zwischen Verschriftung und Verschriftlichung." Verschriftung und Verschriftlichung. Hrsg. Ehler Ch., Schaefer U. Tübingen, 1998. 
Miklas H. Glagolitica : Zum Ursprung der slavischen Sriftkultur. Hrsg. H. Miklas. Wien: Verlag der Österreichischen Akademie der Wissenschaften, 2000.

Rogers H. Writing systems : A linguistic approach. New Jersey: Blackwell Publishing, 2005.

Sawicka I. The Balkan Sprachbund in the light of Phonetic features. Warszawa: Wydawnictwo Energeia, 1997.

Sawicka I. An outline of the Phonetic typology of the Slavic languages. Torun: Wydawnictwo Univesytetu Mikołaja Kopernika, 2001.

Stanišić V. „Slavic digraphia in the context of the Old Slavic literacy.” Serbische und kroatische Schriftlinguistik: Geschichte, Perspektiven und aktuelle Probleme. Hrsg. B. Brehmer, B. Golubović. Hamburg: Verlag Dr. Kovač, 2010: 189-200.

Threatte L. „The Greek Alphabet.” The World's Writing Systems. Ed. by P. T. Daniels, W. Bright. Oxford UP, 1996: 271-280.

Tuttle E. „Adaptations of the Roman alphabet.” The World's Writing Systems. Ed. by P. T. Daniels, W. Bright. Oxford UP, 1996: 633-642.

Ulbrich C. „Prosodic Phrasing in three German Standard Varieties.” University of Pennsylvania Working : Papers in linguistics, volume 12/29 (2006): 361-373.

Velčeva B. „Glagolica, Kyrillica, Orthographie und Sprache.” Symposium Methodianum : Beiträge der Internationalen Tagung in Regensburg zum Gedanken an den 1100. Todestag des hl. Method. Regensburg, 1985: 703-708.

Žagar M. Grafolingvistika srednjovjekovnih tekstova. Zagreb: Matica hrvatska, 2007.

Ваня С. Станишич

ПАРАДИГМАТИКА И СИНТАГМАТИКА НЕСАМОСТОЯТЕЛЬНЫХ ГРАФЕМ И ДВА ТИПА ОРФОГРАФИЧЕСКИХ СИСТЕМ В ЕВРОПЕЙСКИХ ПИСЬМЕННОСТЯХ

Резюме

Темой данной работы является вопрос парадигматического и синтагматического статуса несамостоятельных графем в письменных системах Европы. Обзор их парадигматического и синтагматического статуса может быть полезным для более ясного понимания отношений между языковой основой и графической формой и пролить свет на значительные различия существующие между европейскими письменными системами.

Ключевые слова: парадигматика и синтагматика письма, несамостоятельные графемы, диграфы, лигатуры, диакритики. 